\title{
The Obvious Fraud Revisited: The Admission-Seeking Interview
}

David O'Bryan, Pittsburg State University, USA

Jeffrey J. Quirin, Wichita State University, USA

\begin{abstract}
E.Z. Pickens Conglomerate, S.A. is a large, multi-national manufacturing organization. Approximately six months ago an anonymous tip was left on the company's fraud hotline. The tip pertained to a division manager of the company who had allegedly perpetrated a fraudulent vendor scheme in collaboration with their significant other. Your company's internal audit department conducted a review of the vendor file, corroborated the allegation, and forwarded their findings to your department. You supervised a complete investigation into the matter which will now culminate with an admission-seeking interview of the fraudster. Your task is to review the investigative file, prepare to confront the alleged perpetrator, and then conduct the admission-seeking interview to obtain an oral and written confession.
\end{abstract}

Keywords: Fraud Examination; Forensic Accounting; Interviewing Techniques

\section{INTRODUCTION}

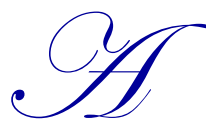

s a fraud examiner for a large, multinational organization with a division in Mexico it is your responsibility to investigate fraud allegations referred to you by the internal audit division. You have just completed a thorough investigation into one such allegation and are confident you have sufficient proof to obtain a confession from the perpetrator. An anonymous tip was the initial predication for this investigation. It simply said, "Pat's significant other is a fraudulent vendor." One of the division managers at your company is named Pat. Based upon this information, the internal audit department conducted a preliminary review of the matter. Their search of the accounts payable (AP) file revealed several questionable invoices. The invoices were for identical amounts but on different dates. There was no documentation to support these transactions other than the invoices. The auditors made some discreet inquiries among Pat's coworkers and learned of a recent relationship between Pat and Kim, a significant other who is not employed at your company. The auditors also learned that Pat had the authority to approve payment of invoices for less than $\$ 10,000$.

The internal audit could have confronted Pat at this point about the allegations (O’Bryan \& Quirin, 2012). However, the internal auditors had recently attended a fraud workshop sponsored by your department in which the point was made that fraud investigations differ from audits in many respects. Allegations of fraud are sensitive matters and require proof, not mere hunches. The auditors wisely chose not to confront Pat, but rather to refer their case to your department for a formal fraud investigation. Approximately six months have elapsed since the initial, anonymous tip. Your fraud examination department has conducted a thorough investigation into this matter, the results of which appear in Exhibits 1-15 in the Appendix. This evidence links Pat to Kim, Kim to one of our vendors, namely Kimco Marketing, and proceeds from your company's checks made payable to Kimco Marketing to an account controlled by your employee, Pat. With this evidence you determine it is now appropriate to conduct an admission-seeking interview with Pat. The objective of this interview will be to obtain an oral and written confession from the perpetrator.

This case extends O'Bryan and Quirin (2012) and is designed to show how the case could have been properly handled. The primary objective of this case is to provide students with an opportunity to use the results of an investigation to conduct an effective, admission-seeking interview using the general approach recommended by the Association of Certified Fraud Examiners (ACFE). 


\section{ASSIGNMENT}

Your class will be divided into teams of two persons each. Your team should assume you are the fraud examiners who will conduct the admission-seeking interview with Pat. The steps in a typical admission-seeking interview are as follows: 1. Direct, confident accusation, 2. Interrupt and delay denials, 3. Reason with the accused, 4. Establish a rationalization, 5. Diffuse alibis with evidence, 6 . Present an alternative question, 7. Reinforce the rationalization, 8. Obtain a verbal confession, and 9. Obtain a written confession. Your task is to review the results of the fraud investigation in the Appendix and prepare to conduct an admission-seeking interview with Pat. One team member should plan to serve as the lead interviewer while the other will assume the role of a witness and note taker.

\section{CASE LEARNING OBJECTIVES AND IMPLEMENTATION GUIDANCE}

\section{Introduction and Objectives}

This case is based upon an actual fraud investigation. In that case they discovered that their division manager was committing fraud at a foreign subsidiary. The company's internal auditors quickly confronted the fraudster and he was soon terminated. The fraudster never admitted any wrongdoing. He is believed to have destroyed key evidence before leaving the organization. Ultimately the fraudster sued the company for wrongful termination and won a six figure settlement for wrongful termination. Improper handling of the investigation resulted in a six figure loss from the embezzlement being compounded by the wrongful termination suit. O'Bryan and Quirin (2012) was designed to allow students to simulate the mistake made by the company investigators so that they could learn the perils of a rush to judgement in a fraud investigation.

The actual investigation in this case did not begin with an anonymous tip. However, anonymous tips are a frequent means of detecting fraud. One example of such a tip occurred in 2011 at Renault (Jones \& Lublin, 2011). Unfortunately, Renault similarly engaged in a rush to judgement resulting in bad publicity for their company. Anonymous tips are often useful in fraud examinations, but they should be handled with due care. The Renault case provides additional motivation for the lesson we are striving to impart in this case. Allegations of fraud should not be based on hunches, but rather on thorough investigations. Renault prematurely fired three top executives. When they learned they had been the victims of an elaborate hoax (Gauthier-Villars, 2011) they issued a public apology to the fired employees (Moffett \& Pearson, 2011). "Renault is the poster child for why you want to approach these situations with a sense of balance, and not have people rush to judgment," according to Robert Fatovic, the chief legal officer at Ryder Systems, Inc. (Jones \& Lublin, 2011).

\section{Motivation}

A number of sources discuss how to properly conduct an admission-seeking interview (e.g., Inbau, Reid, Buckley, \& Jayne, 2013; Zulawski \& Wicklander, 2002; Kranacher, Riley, \& Wells, 2011; Albrecht, Albrecht, Albrecht, \& Zimbelman, 2012). The Association of Certified Fraud Examiners (ACFE) also has useful training resources related to admission-seeking interviews (e.g., ACFE, 2013a; ACFE, 2013b). Coe, Coussens, and Delaney, (2009) incorporate an admission-seeking interview into their case requirements by asking students to critique a recorded interview. This case is designed for students to assume the more active role of being the fraud examiner who is conducting the admission-seeking interview. The case setting, in which a thorough fraud examination has already been conducted, allows students to focus on using the results of the investigation to obtain a confession. The authors are not aware of a published case that provides students with such an experience. The contribution of this case study is not to extend the theoretical literature on admission-seeking interviews, but rather to provide instructors with a case study that will facilitate application of this knowledge.

\section{Implementation}

This case study is designed for an introductory course in fraud examination, forensic accounting, or interviewing and interrogation. It might also be useful in an auditing course to highlight the differing roles of internal auditors and fraud examiners in a typical fraud investigation. The typical student in these classes would be an upper-level, undergraduate student majoring in accounting or criminal justice. 
O'Bryan and Quirin (2012) was framed in an internal audit setting. The internal auditors had predication that a fraud had been committed. Rather than conduct a complete investigation, they confronted the suspect with minimal evidence to support their allegation. This case was designed to show students the incorrect way to approach an admission-seeking interview. This case is an extension that takes place when the internal auditors decided to refer the case to the fraud examination department rather than confront the alleged fraudster. The fraud examination department subsequently conducted a complete investigation and the evidence confirms the initial predication. This extension to the earlier case was designed to give students the opportunity to practice the ACFE's approach to obtaining an oral and written confession.

This mirrors what we often observe in practice in which the internal audit department may initially obtain leads and conduct preliminary investigations into allegations of fraud. If their results confirm the fraud allegations, then internal auditing will refer the case to the fraud examination unit. This allows the auditors to maintain a positive working relationship with their clients while the fraud examiners aggressively pursue the case and confront the fraudster. In effect, the internal auditors remain "good cops" and the fraud examiners are the "bad cops". It also allows for some specialization as conducting a fraud examination is different in several respects from conducting a routine audit. This case is designed to be used after students have completed some study of the admission-seeking interview process. The idea is to have students first study the suggested approach to an admission-seeking interview and then put them in the active role of conducting an admission-seeking interview.

Students will need at least 30 minutes to study Exhibits 1-15 and formulate their interview process and questions. If they follow the recommended approach to an admission-seeking interview, it will take them at least 30 minutes to obtain a confession. We recommend two, successive class periods for this exercise. In the first class period, provide students with the case, group them with a partner, and give them some class time to prepare for the interview. The admission-seeking interview is then conducted in the second class period. As the instructor plays the role of the fraudster, it is important that he or she be evasive so that the interviewers have to be diligent to obtain a confession. It is not uncommon for fraudsters to confess rather quickly when confronted with evidence of wrongdoing. However, we envision this to be a more difficult case so that students will get more experience dealing with a fraudster who is reluctant to admit wrongdoing.

\section{TEACHING NOTES}

Exhibits 1-15 contain the results of the fraud investigation. Exhibits 1-6 are the six fraudulent invoices. The first three invoices occurred before the anonymous tip, while the next three occurred while the examination was ongoing. Exhibits 7-12 are the cancelled checks corresponding to the six invoices. Exhibits 7-9 indicate the checks were endorsed by Kim, while Exhibits 10-12 were first endorsed by Kim and then by Pat. This ties Pat directly to the fraud scheme. Exhibit 13 is a memo from the company's payroll department. From this memo we learn Pat is paying a significant amount of spousal maintenance and child support. This establishes financial need. We can also observe the bank account number from Exhibits 10-12 is the same as the one used for direct deposit of Pat's payroll check. The divorce can also be used to develop a rationalization for the fraud. The interviewer can display empathy to the accused and express their understanding of how such a traumatic event could cause a good person to do something wrong. Exhibit 14 is the report from a private investigator who followed Pat for a week. This report confirms Pat and Kim are involved in a relationship. Hence, we have tied Pat to Kim, Kim to Kimco Marketing, and Kimco Marketing proceeds flowing into Pat's bank account. Exhibit 15 is Pat's employment application from the human resources department. It can be used to learn about Pat's background to help build rapport in the interview. Exhibits 1-15 are designed to provide fairly conclusive evidence that Pat conspired with Kim to commit a fraudulent vendor scheme. The idea is to provide students with solid evidence of fraud and then see if they can utilize this evidence to obtain a confession.

The remainder of this teaching note will provide the instructor with an example script for the simulated interview. It would be impossible to envision every possible scenario that could take place, but the central theme is for the instructor to be elusive enough to force the students to use the ACFE framework for an admission-seeking interview to obtain an oral and written confession. The instructor will need to be creative in formulating their own responses to unforeseen questions. 


\section{The Admission-Seeking Interview}

In the following sample interview script we depict how the admission-seeking interview might progress. The interviewee in this script initially attempts to stall the interviewers, but the interviewer overcomes this resistance and is able to continue the interview. Alternatively, the interviewee/instructor could initially refuse to cooperate and/or request that an attorney be present. The interviewer may be able to overcome this response by reminding the interviewee that it is company policy that all employees cooperate with internal investigations. Furthermore, since no state action is involved there is no constitutional requirement that an attorney be present; of course, the interviewee can still refuse to cooperate, but the interviewer can remind them of their duty to cooperate or face sanctions from the organization. Ideally, the interviewer will use persuasion and appeal to self-interest to convince the interviewee that it is in their best interest to cooperate. It will be up to the instructor to determine whether the interviewer has effectively overcome the interviewee's resistance to participate in the interview.

Ashlee is the interviewer in this sample script. Note that throughout the interview Ashlee uses non-threatening language and displays empathy to Pat.

(Begin Interview Script)

Knock, Knock.

Pat: Yes.

Ashlee: Good afternoon Pat. My name is Ashlee. I was just reviewing some paperwork, and I need to ask you a few questions.

Pat: Can it wait? This has been a hectic day.

Ashlee: I understand, but I checked with your supervisor and she said it would be fine for you to visit with me for a few minutes.

Pat: Oh. Well, fine. Come on in then.

Ashlee: Actually, I reserved the conference room just down the hall. Let's grab some coffee and go down there.

Pat: Ok. Let me grab my phone so I can monitor emails while we visit.

Ashlee: That won't be necessary. We won't be long.

(An admission-seeking interview is best conducted in a neutral location with no distractions. Electronic devices are troubling since they would potentially allow Pat to communicate with Kim or others during the admission-seeking interview.)

The two leave Pat's office to walk to the conference room.

Pat: I hope this won't take long.

Ashlee: No, no. Just a few questions so I can dot some I's and cross some T's. You have no idea how picky my boss can be sometimes.

The two are seated in a conference room.

Ashlee: Pat, first I want to thank you for meeting with me. I appreciate your time.

Pat: Sure. 
Ashlee: You know we have quite a bit in common. We have degrees from the University of Arkansas.

Pat: Really? We're both Razorbacks? That is pretty neat!

Ashlee: Yeah, and we both majored in business too.

Pat: Ironic we'd both end up here.

Ashlee: That's what I thought. We both got shipped down here to help get this new division up and running. They probably knew they could trust a couple of Razorbacks to get the job done correctly.

Pat: Yeah, I guess. Don't you wish we were back at Fayetteville? This is not exactly a tourist destination.

Ashlee: Oh, I understand completely. I'm hoping to get reassigned back home soon.

Pat: Yeah, me too.

(In this brief introductory period, Ashlee is developing rapport with Pat. It is important that Pat feels as though he can talk openly with Ashlee. The common bond between them should help Pat feel that he can trust Ashlee and that Ashlee understands Pat.)

Ashlee: So, Pat, could I ask you a few questions about some invoices you approved for Kimco Marketing?

Pat: (A bit stunned when he hears Kimco Marketing). Kimco Marketing? Not sure I remember approving any invoices for them.

Ashlee: (Laying down Exhibit 1). Perhaps this will help. You can see you approved payment.

Pat: Yes, I guess I did, but that was over a year ago.

Ashlee: I understand, but you did approve payment?

Pat: Yes, I guess I did but I approve a lot of bills so it's hard to remember all of them, especially ones from a long time ago.

Ashlee: Now, Pat, it is really important for you to think about this before you answer. Was this a legitimate vendor?

Pat: Yes, yes. I mean I thought it was or I would not have approved payment. Did someone deceive me?

\section{Step 1: The Accusation}

Ashlee: Pat, we know you submitted some invoices for Kimco Marketing and that this vendor did not do any work for our company. Why did you do this?

Pat: Do what? I didn't do anything. Look, if something's wrong I can promise you it is one of these locals. They don't understand right from wrong. I can swear to you that I did nothing wrong.

\section{Repeat the Accusation}

Ashlee: No, Pat. YOU submitted false invoices for Kimco Marketing. Why did you do this?

Pat: I already told you I didn’t. Why don’t you believe me? I wouldn't lie to a fellow Razorback.

(Notice that Ashlee did not ask Pat if he committed the fraud. Rather, she asked Pat why he committed the fraud. 
She is projecting confidence in her allegations.)

\section{Step 2: Interrupt and Delay Denials}

Ashlee: Pat, this has been a tough assignment for all of us. I understand why you might have done something improper.

Pat: I didn't do anything. This is crazy. I don't have to put up with this.

Ashlee: I'm sorry. I didn't mean to upset you, but we need to talk about this. You need to be straight with me about what you did.

Pat: I swear I didn't do anything. I am the type of person who never misses church on Sundays.

Ashlee: I know you are a good person. It is pretty clear you are a good person, but you need to be honest with me.

Pat: I am being honest. Why don't you believe me?

\section{Step 3: Reason with the Accused}

Ashlee: Look, Pat, I want to believe you, but the facts tell a different story.

Pat: What facts? There can't be any facts that prove I did anything wrong. Maybe some of my employees are just mad at me and this is their way of getting even with me. Have you thought about that?

Ashlee: We have done an extensive investigation into this matter and the evidence proves you submitted improper invoices. The best thing you can do is just be truthful about all of this.

Pat: Investigation? I don't understand why I'm being investigated. I didn't do anything wrong. I work my tail off for this company.

Ashlee: Of course you do, Pat. Everyone here knows how hard you work and how loyal you are to our company. But the facts are that you submitted improper invoices for Kimco Marketing and that you shared the money with your girlfriend Kim.

Pat: No. You're wrong. This can't be true. You're wrong.

\section{Step 4: Establish a Rationalization}

Ashlee: Look, Pat, your friends told me your marriage fell apart after you were transferred down here. I can understand why you would be upset with the company.

Pat: Yeah. She was my high school sweetheart. A long-term relationship ruined because of this rotten assignment. No one really even asked me if I wanted to come here. They just patted me on the back and told me it was a promotion.

Ashlee: It must be real tough to lose someone you love. It puts you under a lot of pressure.

Pat: Yes, not to mention the spousal maintenance and child support.

Ashlee: Of course, emotional pressure and financial pressure. We're human beings. We make mistakes.

Pat: The only mistake I made was accepting this assignment. I should have left the company. 


\section{Step 5: Diffuse Alibis with Evidence}

Ashlee: Pat, you know that's not the only mistake you made. You submitted improper invoices to our company.

Pat: It just isn't true.

Ashlee: (Displaying Exhibits 7-9). Pat, look at these checks. You can see that Kim was endorsing the checks to Kimco Marketing.

Pat: Yes, I guess someone named Kim must own the business. So what?

Ashlee: Pat, you know who Kim is don’t you?

Pat: Hey, I've got an active social life now that I'm divorced. No law against a guy dating is there?

Ashlee: No, but you are in a relationship with Kim aren't you?

Pat: I don't really remember names very well. Maybe if you had a picture of her I could help you.

Ashlee: (Displaying the pictures from Exhibit 14.) Actually, we do have several pictures of the two of you together. That is you with Kim isn't it?

Pat: (Delay and silence.) I guess it is. She has the most intriguing accent.

Ashlee: I know. We talked to Kim.

(The interviewer actually did not talk to Kim, but is entitled to embellish a bit as long as it would not make an innocent person confess.)

Pat: You talked to Kim? About this invoice?

Ashlee: Yes. She was very nice.

Pat: That little tramp. After all I did for her.

Ashlee: Pat, we're Razorbacks. We can talk. I know you want to tell me the truth, but it's hard after all you've been through. It's difficult for you isn't it?

Pat: The past six months have been tough, but I never committed any fraud. I dated Kim and she owns Kimco Marketing, but there's no fraud.

Ashlee: (Displaying Exhibits 10-12.) Pat, I have three more checks to Kimco Marketing. After Kim endorsed them, you can see your signature endorsement on them. The money went from our company, to Kimco Marketing, and then to you.

Pat: There's never enough money in my bank account after the divorce.

Ashlee: Times are tough for everyone these days. I don't blame you for not wanting to talk about this, but we need to resolve this today. In fact, we need to resolve this now. It's best for both of us.

Pat: It is?

Ashlee: Yes. I want to be able to tell my boss that you cooperated. I want to be able to tell my boss that you made a mistake but you acknowledged it. 
Pat: I know you want to help.

(Note that Ashlee methodically presented her evidence in reverse order of importance. She presented the most damaging evidence at the last only after she could not convince Pat to confess earlier.)

\section{Step 6: Present an Alternative Question}

Ashlee: Pat, we've got a lot in common. You can talk to me. I think you're a good person. Did you do this out of greed or did you just really need the money?

Pat: The money just never goes far enough at the end of the month and I can't ever seem to get my bonus.

Ashlee: So you did it because you really needed the money?

Pat: Yes. (Hanging his head)

(Note how the alternative question is worded. The first reason given is greed, which sounds negative. The second reason is financial need, which is easier to accept. The alternative question should always end with a reason that is less sensitive and easier to acknowledge.)

\section{Step 7: Reinforce the Rationalization}

Ashlee: You know you're doing the right thing to share this with me? You are a good person who just made a mistake. Who could blame you after the company ruined your marriage?

Pat: It made me bitter. I was never a bitter person before.

Ashlee: Of course it did. Now is the time for a fresh start. This is a time to put all of this behind you.

Pat: I need a fresh start.

\section{Step 8: Verbal Confession}

Ashlee: Of course you do. Tell me how this happened.

Pat: It was all Kim's idea. She's a devious person, but I didn't know that until later. She preys on foreign nationals. She told me she would submit the invoices, and all I would have to do is approve them and we'd have some extra spending money.

Ashlee: But you knew this was wrong?

Pat: I did, but it seemed alright when she was saying it. That foreign accent just swept me away. I wasn't thinking straight.

Ashlee: So how many times did you do this?

Pat: I think there were four invoices.

Ashlee: We found six.

Pat: It was definitely not more than five times.

Ashlee: I understand it was a long time ago. What did you do with the money?

Pat: Spent it on Kim. We were going to get married. She said she loved me. 
(Note that Ashlee does not argue with Pat about whether there were five or six invoices. If she can get Pat to confess to five invoices there may not be much incremental gain from arguing about the sixth invoice, especially not if it would damage the rapport she has established with him. If the matter is pursued further, the sixth invoice can easily be documented.)

\section{Step 9: Written Confession}

Ashlee: Maybe she did. It's time for a fresh start, remember? You did the right thing by telling me about this. Now, I need you to do one more thing.

Pat: Thank you for being so kind about all of this.

Ashlee: I have no reason not to like you Pat. You're not a bad person. I just need you to sign this statement.

(Ashlee presents Pat with a written statement.)

Pat: Am I going to lose my job?

Ashlee: I can't promise you anything, but I'm going to tell my supervisor that you cooperated. And, I am going to mention that you appear to be a good person who was just under a lot of pressure.

Pat: (Head in his hands). I can't believe I fell for her so hard. I just can’t believe this all happened to me.

Ashlee: We've all done some crazy things for love. I think everyone understands how relationships make us do things we later regret.

Pat: You're making this a lot easier. I can tell you care.

Ashlee: Of course I care. We have a lot in common remember? Here's a pen so you can sign the statement.

Pat: Can I read it first?

Ashlee: Of course. Take your time.

Pat: It says six invoices here. There were only five.

Ashlee: Yes. Just cross out six and write five with your initials next to it.

Pat: May I write a bit more to explain why I did this? I want people to understand my side of the story.

Ashlee: Of course. You can just add a few sentences at the bottom.

Pat: Thank you.

(Pat writes a few sentences and then signs the written confession. Note that by having Pat make a change to the confession and initial it she has strengthened her case. If Pat later tries to contend that he did not read the confession she can point to the initials in the middle of the document to refute his claim. In addition, fraudsters often like to tell their side of the story and there is no reason not to allow this; the important part is to continue to encourage cooperation and obtain a signed confession.)

\section{(End Interview Script)}

In this example script, the interviewee ultimately provides an oral and written confession. Alternatively, the instructor may choose to not provide a confession if he or she feels the interviewer has not effectively conducted the 
admission-seeking interview. In this case, a follow-up critique of the interview can useful to recommend areas for improvement.

\section{AUTHOR BIOGRAPHIES}

David O'Bryan, Ph.D., CPA, CFE, CMA, is a Professor in the Department of Accounting and Computer Information Systems at Pittsburg State University (PSU), Pittsburg, Kansas. He earned a doctorate in Accountancy from the University of Missouri at Columbia in 1992. His teaching areas include Financial Accounting, Fraud Examination, and Management Control Systems. He also provides litigation advisory services on forensic accounting matters.

Jeffrey J. Quirin, Ph.D., CMA, is a Professor in the School of Accountancy at Wichita State University (WSU), Wichita, Kansas. He earned a doctorate in Accountancy from the University of Nebraska-Lincoln in 1998. His teaching areas include Financial Accounting and Managerial Accounting. Through his extensive work as a litigation consultant, he has served in the capacity of Court-appointed special master and mediator on numerous occasions.

\section{REFERENCES}

Albrecht, W., Albrecht, C. Albrecht, C., \& Zimbelman, M. (2012). Fraud Examination. Fourth edition. Mason, OH: SouthWestern, Cengage Learning.

Association of Certified Fraud Examiners (2013a). Beyond the numbers: Professional interviewing techniques. December. Austin, TX.

Association of Certified Fraud Examiners (2013b). Conducting Admission-Seeking Interviews. May. Austin, TX.

Coe, M., Coussens, J., \& Delaney, J. (2009). Something's fishy at Jones company. Fraud Magazine, (May/June): $24+$.

Gauthier-Villars, D. (2011). Police probe if Renault was victim of fraud in spy case. Wall Street Journal, (March 14 ): B1.

Inbau, F., Reid, J., Buckley, J., \& Jayne, B. (2013). Criminal interrogation and confessions. Fifth edition. Burlington, MA: Jones $\&$ Bartlett Learning.

Jones, A. \& Lublin., J. (2011). Firms revisit whistleblowing. Wall Street Journal (March 14): B5.

Kranacher, M., Riley, R., \& Wells, J. (2011). Forensic Accounting and Fraud Examination. Hoboken, NJ: John Wiley \& Sons, Inc.

Moffett, S. \& Pearson, D. (2011). Renault apologizes to fired employees. Wall Street Journal (March 15): B1.

O’Bryan, D. \& Quirin, J. (2012). The Obvious Fraud: A Short, Problem-Based Case Study to Highlight Inappropriate Fraud Examination Techniques. Journal of Forensic \& Investigative Accounting (July - December): 292-308.

Zulawski, D. \& Wicklander, D. (2002). Practical aspects of interview and interrogation. Second edition. Boca Raton, FL: CRC Press. 


\section{APPENDIX}

Exhibit 1: Invoice Number 10001

\section{Kimco Marketing \\ Marketing Specialists for the Mexican Region \\ La Quemada 3909, Benito Juarez \\ 03020 Ciudad de Mexico}

INVOICE

February 20, 2011

Pat U. Lyonsack

E. Z. Pickens Conglomerate, S. A.

Andres Bello 29

Mexico City, Distrido Federal 11560 Mexico

+525555194698

Invoice Number: 10001

\begin{tabular}{|l|l|r|}
\hline DATE & DESCRIPTION & AMOUNT \\
\hline $1 / 10 / 2011$ & Marketing Fieldwork & $\$ 3500.00$ \\
\hline $1 / 22 / 2011$ & Market Research & 3000.00 \\
\hline $2 / 1 / 2011$ & Marketing Support Services & 3250.00 \\
\hline
\end{tabular}

Please remit the total amount due within 10 days.

Thank you,

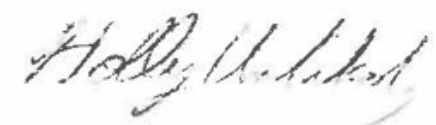

Holly Unlikely, Billing Clerk

approved by: baf A. Gyousode 
Exhibit 2: Invoice Number 25394

\section{Kimco Marketing \\ Marketing Specialists for the Mexican Region \\ La Quemada 3909, Benito Juarez \\ 03020 Ciudad de Mexico \\ INVOICE}

May 25, 2011

Pat U. Lyonsack

E. Z. Pickens Conglomerate, S. A.

Andres Bello 29

Mexico City, Distrido Federal 11560 Mexico

+525555194698

Invoice Number: 25394

\begin{tabular}{|l|l|r|}
\hline DATE & DESCRIPTION & AMOUNT \\
\hline $3 / 25 / 2011$ & Marketing Fieldwork & $\$ 3500.00$ \\
\hline $4 / 5 / 2011$ & Market Research & 3000.00 \\
\hline $4 / 23 / 2011$ & Marketing Support Services & 3250.00 \\
\hline
\end{tabular}

Please remit the total amount due within 10 days.

Thank you,

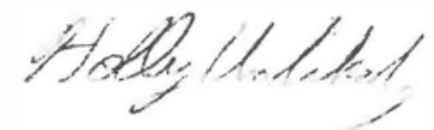

Holly Unlikely, Billing Clerk

Approved by: fat M. Lyorak 
Exhibit 3: Invoice Number 28311

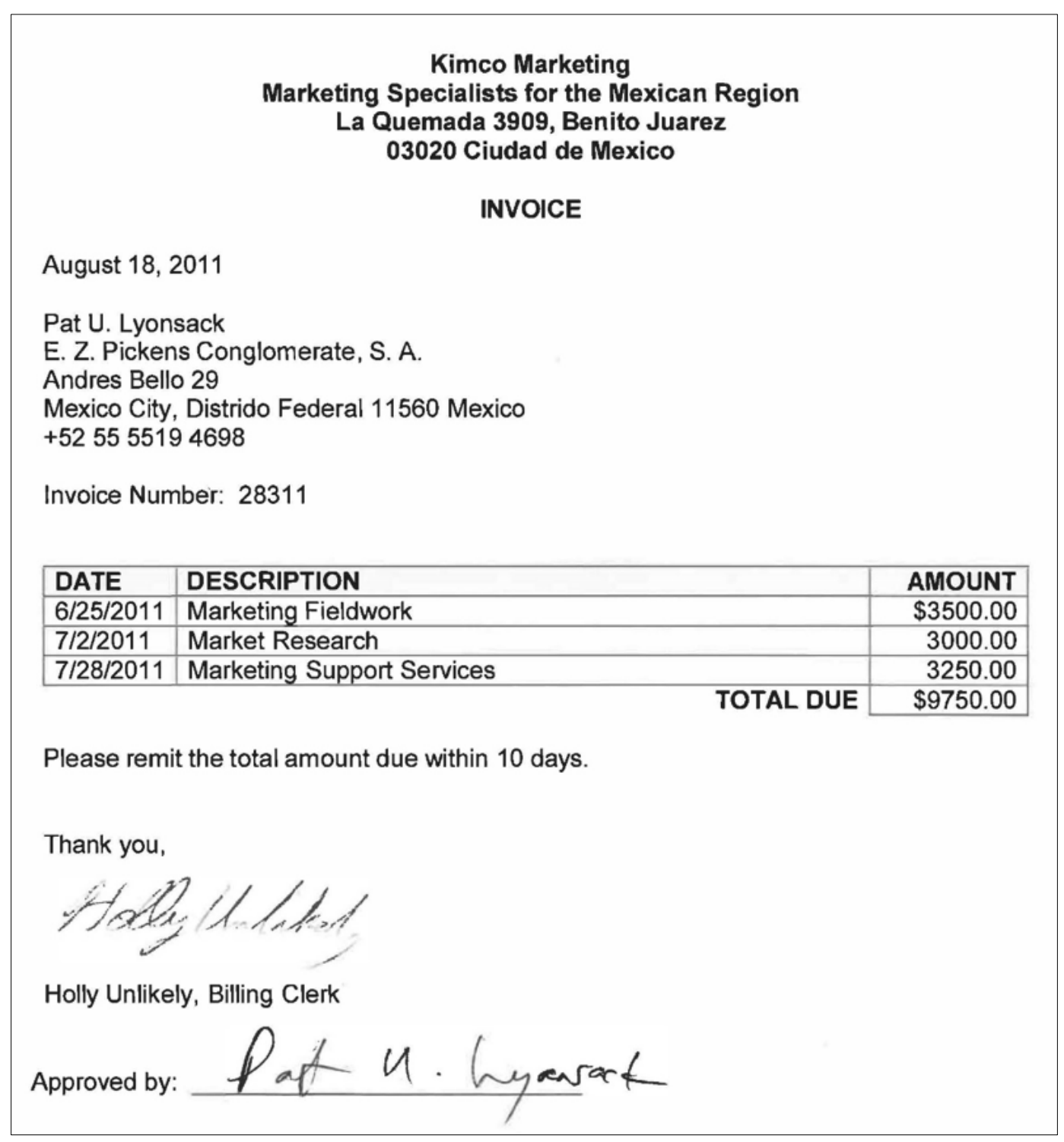


Exhibit 4: Invoice Number 31125

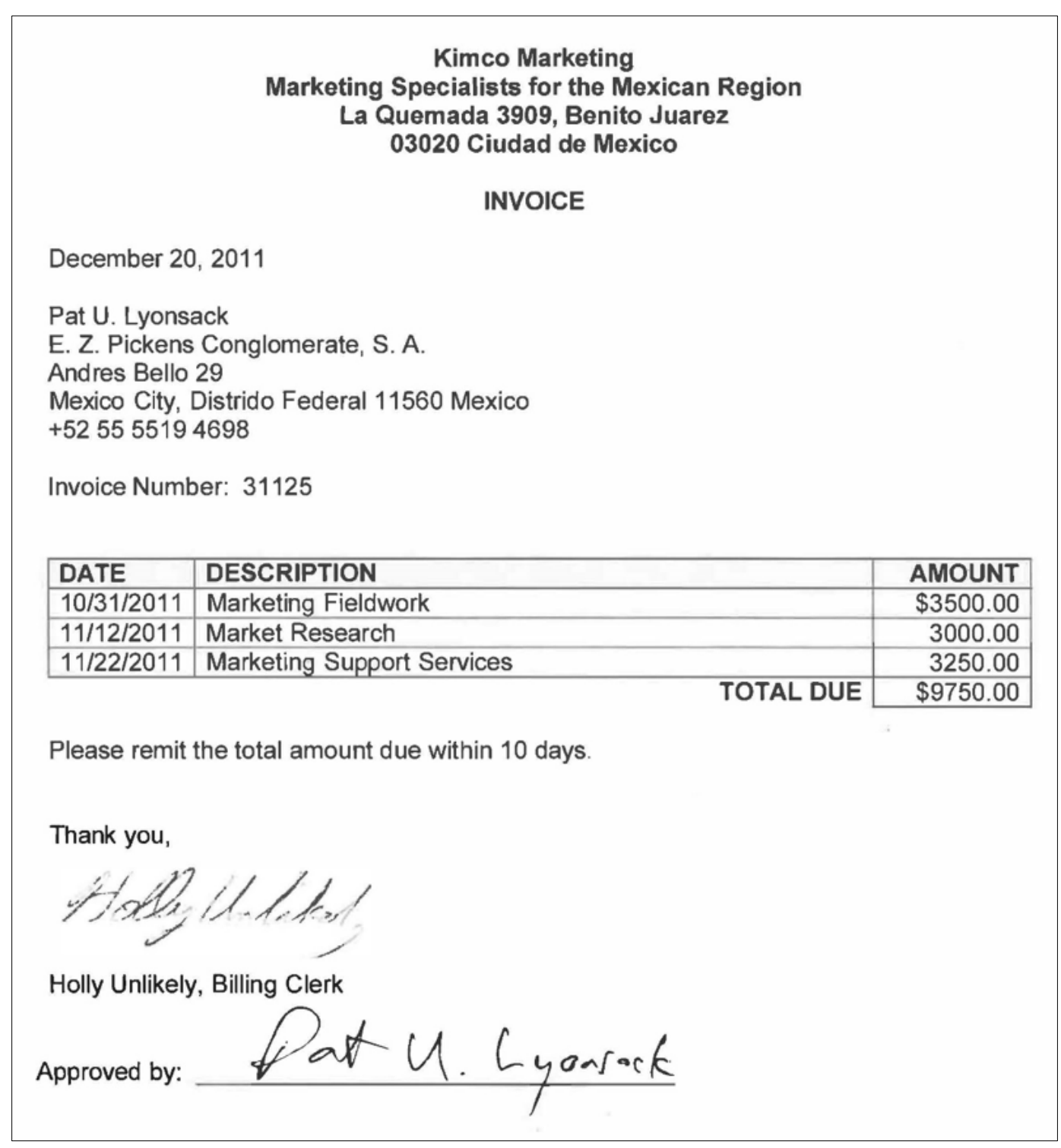


Exhibit 5: Invoice Number 48111

\section{Kimco Marketing \\ Marketing Specialists for the Mexican Region \\ La Quemada 3909, Benito Juarez \\ 03020 Ciudad de Mexico \\ INVOICE}

February 10, 2012

Pat U. Lyonsack

E. Z. Pickens Conglomerate, S. A.

Andres Bello 29

Mexico City, Distrido Federal 11560 Mexico

+525555194698

Invoice Number: 48111

\begin{tabular}{|l|l|r|}
\hline DATE & DESCRIPTION & AMOUNT \\
\hline $1 / 5 / 2012$ & Marketing Fieldwork & $\$ 3500.00$ \\
\hline $1 / 23 / 2012$ & Market Research & 3000.00 \\
\hline $2 / 4 / 2012$ & Marketing Support Services & 3250.00 \\
\hline
\end{tabular}

Please remit the total amount due within 10 days.

Thank you,

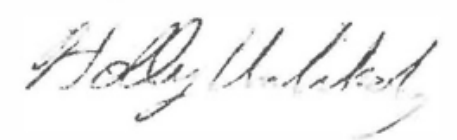

Holly Unlikely, Billing Clerk

Approved by: $\mathrm{R}$ apd U. C yourak 
Exhibit 6: Invoice Number 48321

\section{Kimco Marketing \\ Marketing Specialists for the Mexican Region \\ La Quemada 3909, Benito Juarez \\ 03020 Ciudad de Mexico \\ INVOICE}

March 1, 2012

Pat U. Lyonsack

E. Z. Pickens Conglomerate, S. A.

Andres Bello 29

Mexico City, Distrido Federal 11560 Mexico

+525555194698

Invoice Number: 48321

\begin{tabular}{|l|l|r|}
\hline DATE & DESCRIPTION & AMOUNT \\
\hline $2 / 14 / 2012$ & Marketing Fieldwork & $\$ 3500.00$ \\
\hline $2 / 22 / 2012$ & Market Research & 3000.00 \\
\hline $2 / 25 / 2012$ & Marketing Support Services & 3250.00 \\
\hline \multicolumn{2}{|r|}{ TOTAL DUE } & $\$ 9750.00$ \\
\hline
\end{tabular}

Please remit the total amount due within 10 days.

Thank you,

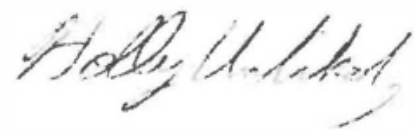

Holly Unlikely, Billing Clerk

Approved by: 
Exhibit 7: Check Number 001089
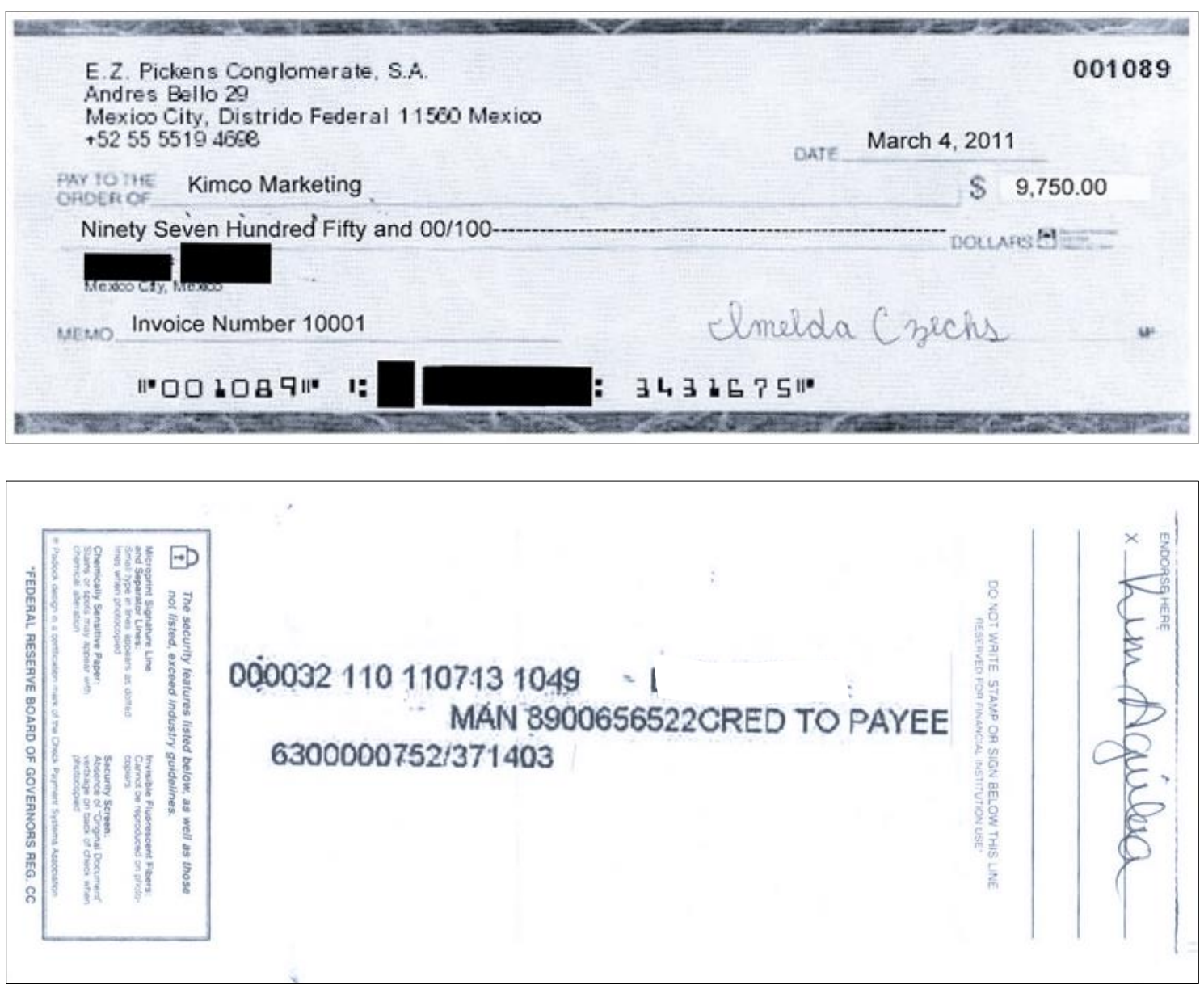
Exhibit 8: Check Number 002011
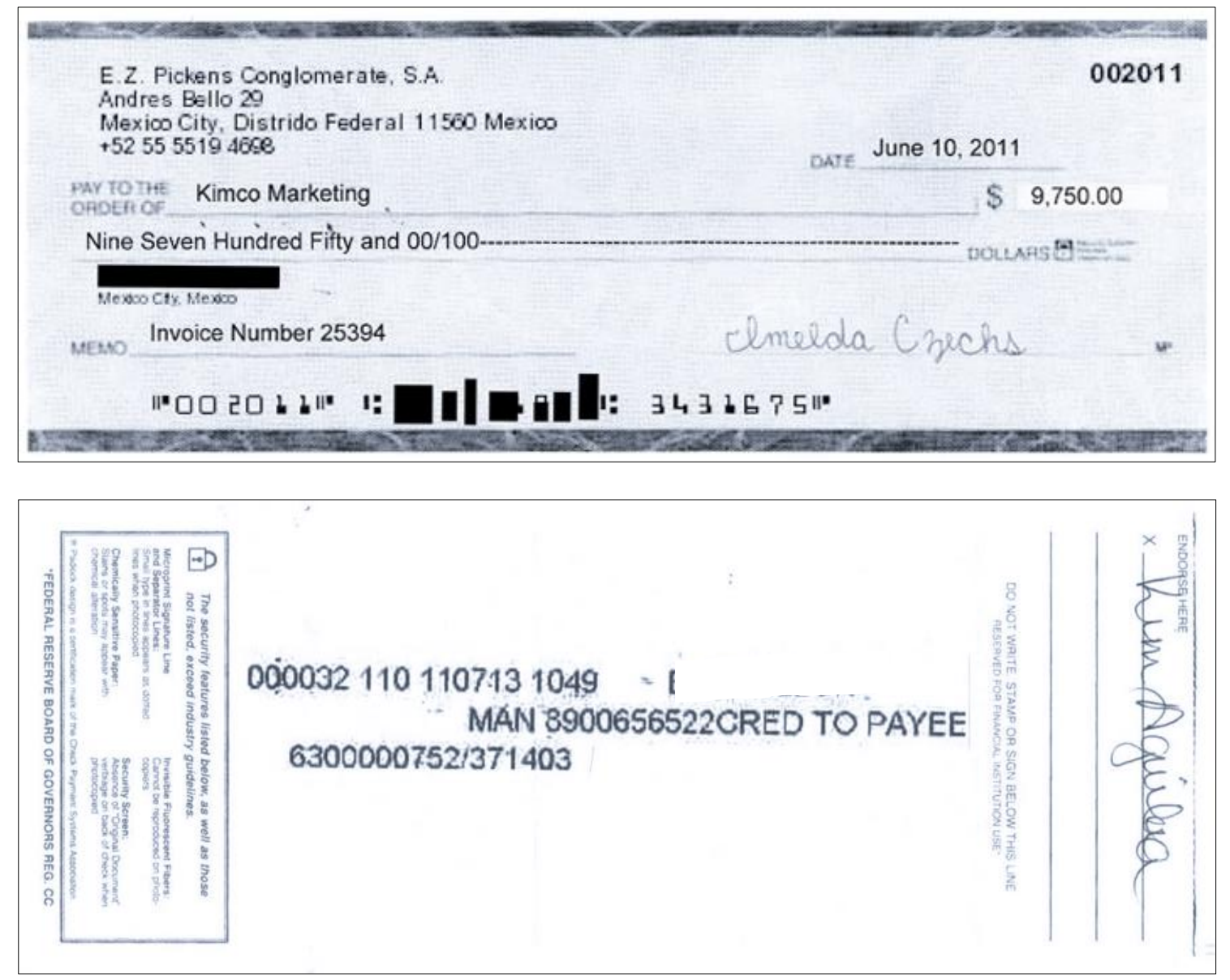
Exhibit 9: Check Number 002078
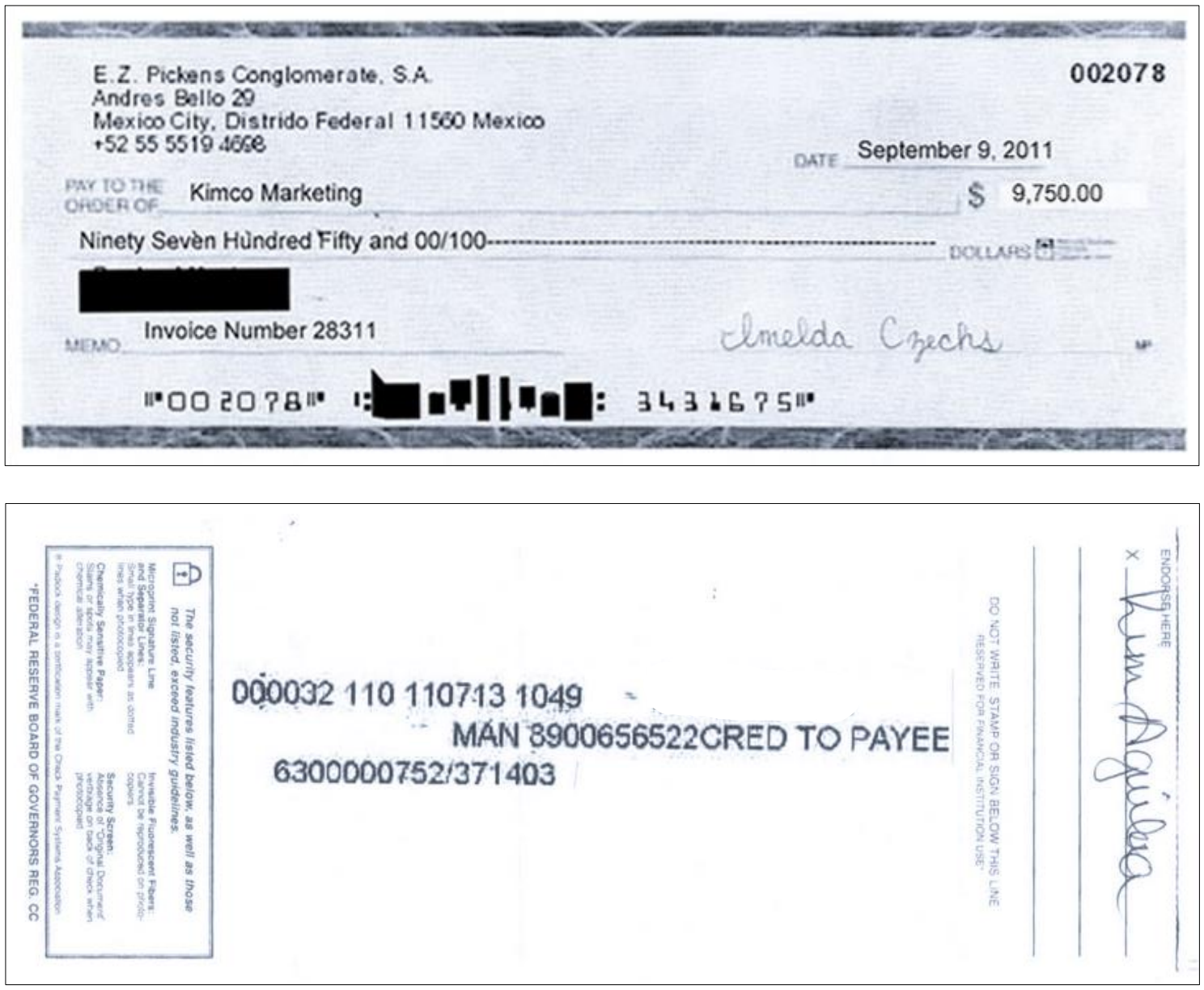
Exhibit 10: Check Number 002097
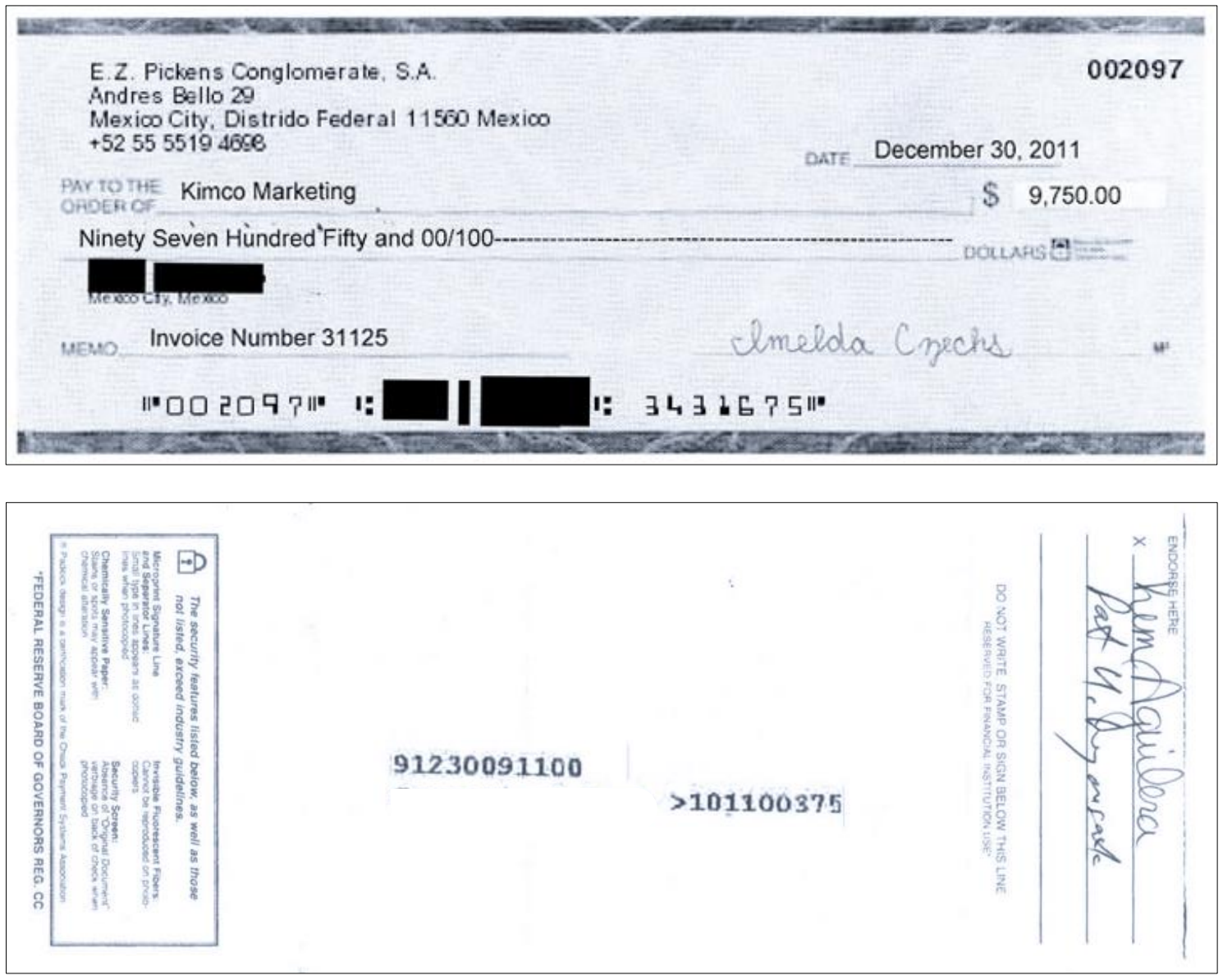
Exhibit 11: Check Number 003015
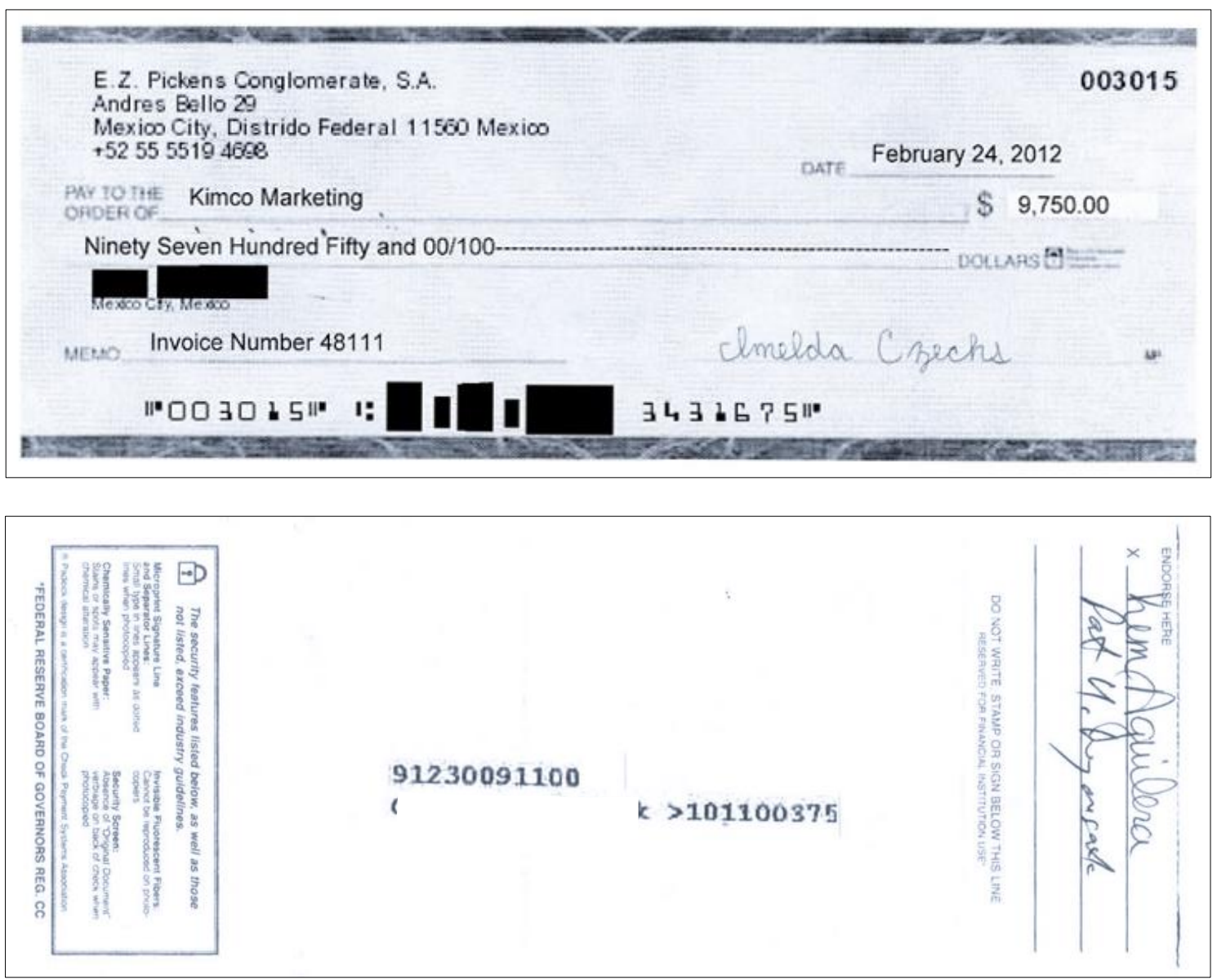
Exhibit 12: Check Number 003057
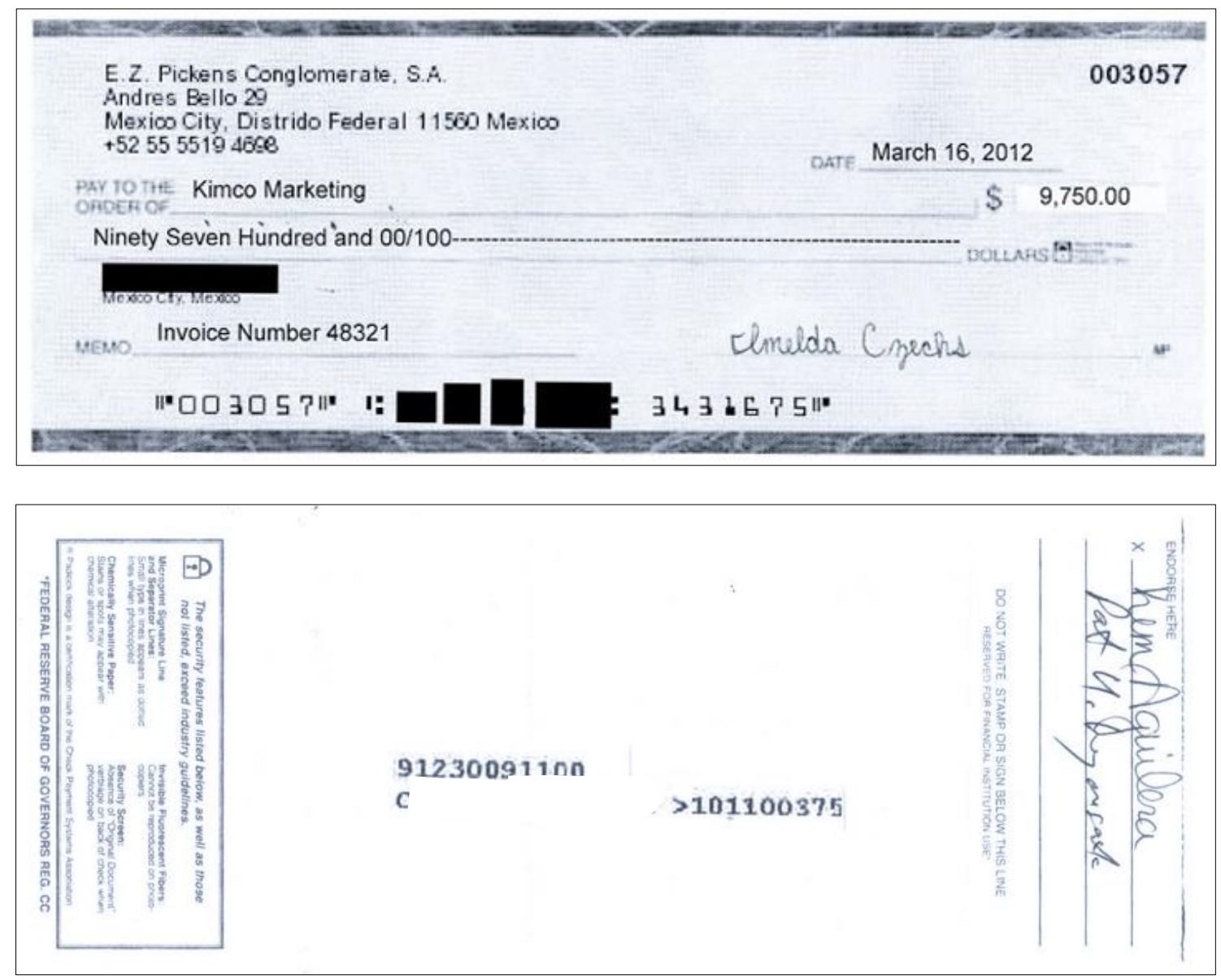
Exhibit 13: Payroll Information for Patrick U. Lyonsack

To: Ms. Ashlee Phillips, E.Z. Pickens Conglomerate, S.A. Fraud Examination

From: Ms. Jeri Vergara, E.Z. Pickens Conglomerate, S.A. Payroll Supervisor

Date: December 19, 2011

Subject: Payroll Information for Patrick U. Lyonsack

Per your request, I am providing certain information concerning the gross pay, deductions, and net pay of Mr. Patrick U. Lyonsack. Mr. Lyonsack was initially-employed by E.Z. Pickens Conglomerate, S.A. on June 1, 2007 as a division manager at the Northwest Arkansas Regional Office in Bentonville, AR. He then transferred to his current position of division manager at the Central America Regional Office in Mexico City on July 1, 2010.

Mr. Lyonsack is currently paid an annual salary of $\$ 122,629$. Like all other employees at the Central America Regional Office, he is paid via direct deposit in bi-weekly intervals. His corresponding gross pay per pay period is $\$ 4,716.50$. Prior to the January 7, 2011 pay date, Mr. Lyonsack's earnings were deflated by payroll deductions for taxes, health insurance, and retirement. These deductions totaled $\$ 1,615.01$ per pay period resulting in net pay of $\$ 3,101.49$ per pay period. His payroll check is direct deposited into account xxxxx0375.

On December 15, 2010, our office received an income withholding order from the State of Arkansas for spousal maintenance and child support payments owed by Mr. Lyonsack to his former spouse. Commencing with the January 7, 2011 paycheck, additional bi-weekly deductions for spousal maintenance in the amount of $\$ 943.30$ and child support in the amount of $\$ 830.77$ were withheld. These additional withholdings reduced Mr. Lyonsack's net bi-weekly pay to $\$ 1,327.42$. His bi-weekly gross pay, deductions, and net pay have remained at these same levels since January 7, 2011. 
Exhibit 14: Private Investigation Report

Thomas T. Hall, PI

Mexico Investigations

Aldama 333,

Colonia Centro

San Miguel de Allende (city)

Guanajuato (state)

Mexico CP 37700

January 10, 2012

Ms. Ashlee Phillips

Division of Fraud Examination

E.Z. Pickens Conglomerate, S.A.

Andres Bello 29

Mexico City Distrido Federal 11560 Mexico

Re: Investigation of Patrick U. Lyonsack

Dear Ms. Phillips:

Per your request, I have performed certain surveillance procedures regarding one of your employees, Patrick U. Lyonsack (SS\# 111-55-7890). I conducted these procedures for a five-day period commencing at 5:00pm on December 23, 2011 and ending at 5:35pm on December 28, 2011. What follows is a summary of my findings during this five-day period concerning the observed trends and behaviors of Mr. Lyonsack outside of the time spent at his place of employment.

Shortly after 5:00pm on Friday, December 23, Mr. Lyonsack departed office building F from the east doors and entered a 2010 Chevrolet Camaro located in parking lot F on the E.Z. Pickens Conglomerate, S.A. campus in Mexico City. According to public information sources, this vehicle is registered to Mr. Lyonsack. Mr. Lyonsack then drove directly to 154 El Matador Drive which is a residence located in the eastern portion of Mexico City. He arrived at the residence at 5:32 pm. Through publicly available sources, I have confirmed this residence to be owned by Kim Aguilera. A 2011 Cadillac Escalade parked in the driveway of the residence possessed a personalized Federal District license plate inscribed "KimCo". According to public sources, the vehicle is registered to Kim Aguilera. Mr. Lyonsack entered the aforementioned residence at his own will and was grasped by someone as he walked in the door. He remained there until 7:05pm at which time he vacated the residence alongside a young lady who was wearing a black coat, blue jeans, and brown boots. The couple left on foot, and I was able to photograph the two of them embracing approximately two blocks west of the aforementioned residence. I have embedded the image taken herein for your review. The couple then walked to a nightclub in the east-central part of Mexico City. They remained there until 1:35am at which time they proceeded to walk back to $154 \mathrm{El}$ Matador Drive. During the walk back to the residence, I witnessed the two kissing on occasion and also exchanging other seemingly romantic gestures. Mr. Lyonsack remained inside the residence until 1:05pm on December 24, 2011. 


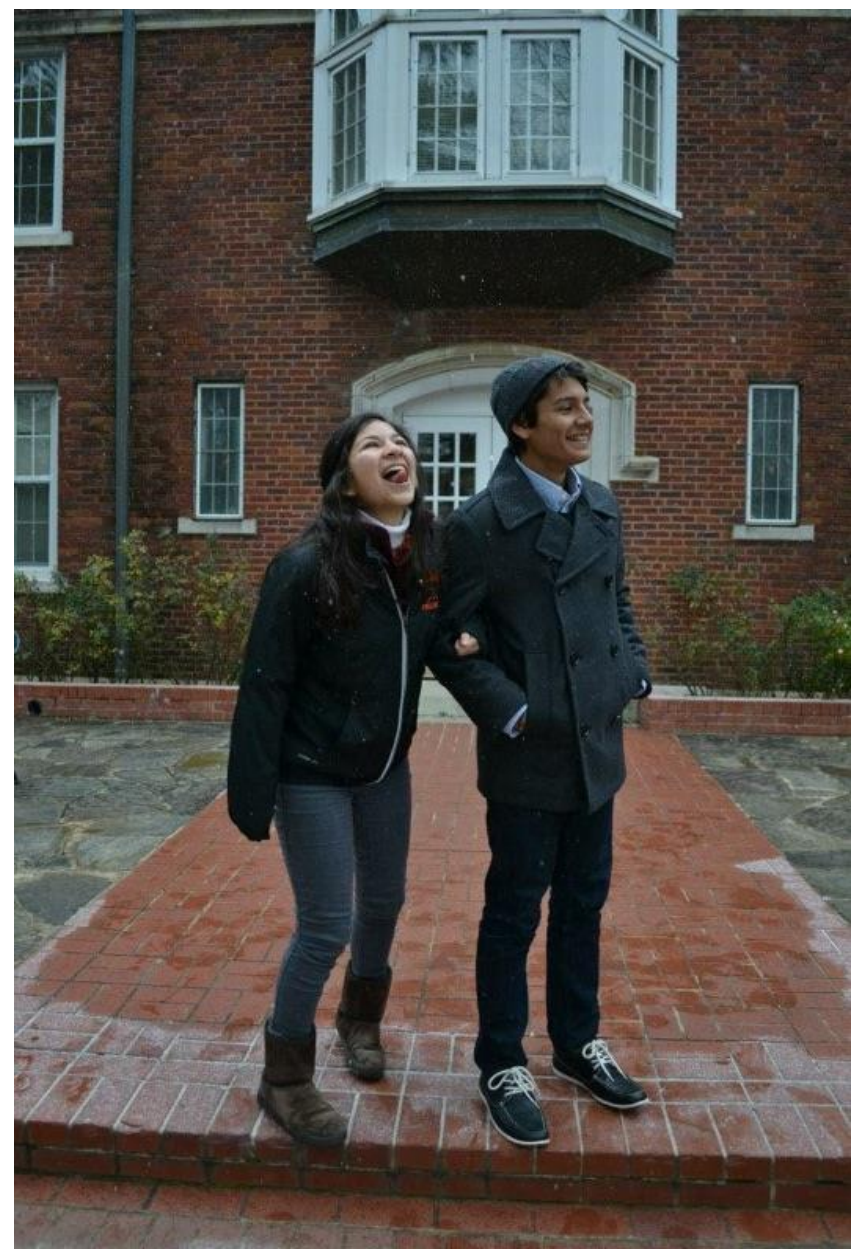

(Photo of Patrick U. Lyonsack and companion taken at approximately 7:10pm on December 23, 2011)

On Saturday, December 24, Mr. Lyonsack and the same female companion left 154 El Matador Drive at 1:05pm via Mr. Lyonsack's 2010 Chevrolet Camaro. They drove directly to 7900 Trofeo which is a residence located in the northwestern portion of Mexico City. The residence, according to public sources, is owned by Adam L. Aguilera. The female left the automobile, entered the residence, and stayed there for a very short period of time. As the female left the residence, I witnessed her holding and subsequently kissing a child who appeared to be two or three years of age. Mr. Lyonsack remained in his vehicle during that time. When the female departed the residence, she was wearing an orange blouse and multi-colored skirt. The two then traveled to the El Coach shopping center located in a very upscale, Mexico City neighborhood. I was able to capture the two of them via photograph shortly thereafter playing a game of billiards prior to eating lunch in a restaurant and cantina. As part of my surveillance, I was also monitoring social media sites used by Ms. Aguilera and Mr. Lyonsack. Shortly after the couple left the aforementioned restaurant and cantina, Ms. Aguilera posted a photo of the two of them together eating lunch. I downloaded this photo. I have embedded the image taken by me inside the restaurant as well as Ms. Aguilera's social media photo herein for your review. The two stayed in the El Coach shopping area until 7:30pm at which time they traveled back to $154 \mathrm{El}$ Matador Drive. Mr. Lyonsack left his companion at the residence and traveled to 456 Conquer Avenue which, according to public sources, is a residence owned by him. Mr. Lyonsack did not leave 456 Conquer Avenue until Monday, December 26 at approximately 7:30am. 


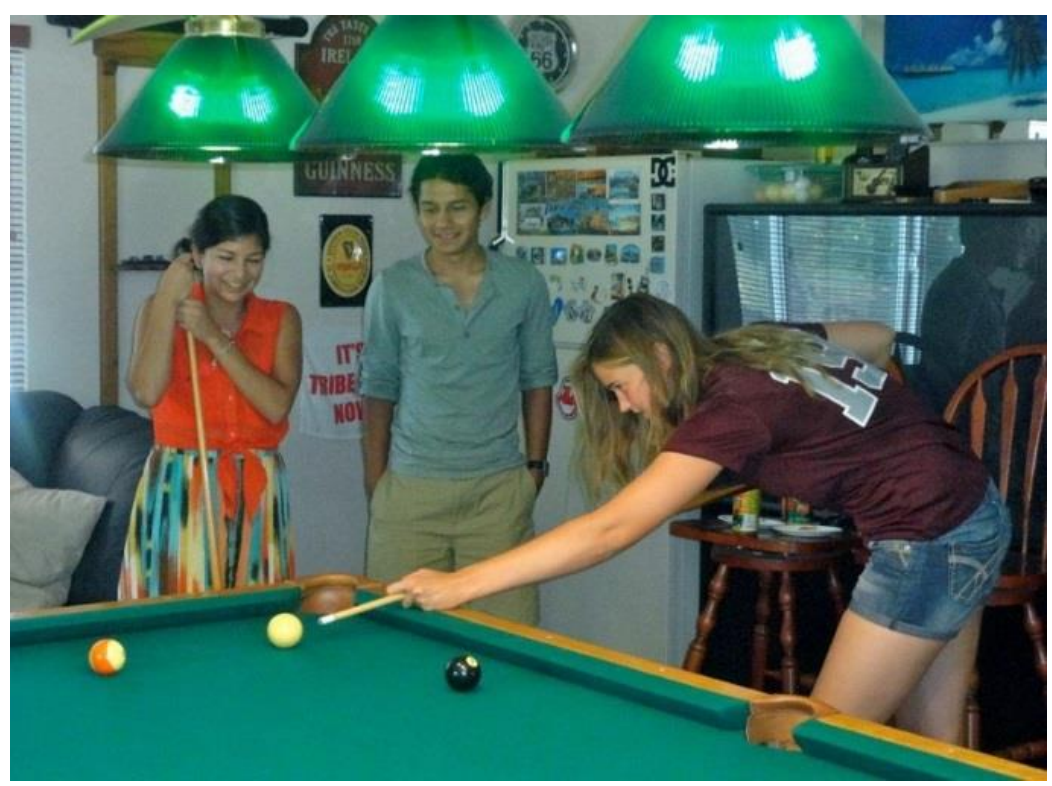

(Photo of Patrick U. Lyonsack and companion taken at approximately 2:15pm on December 24,2011 )

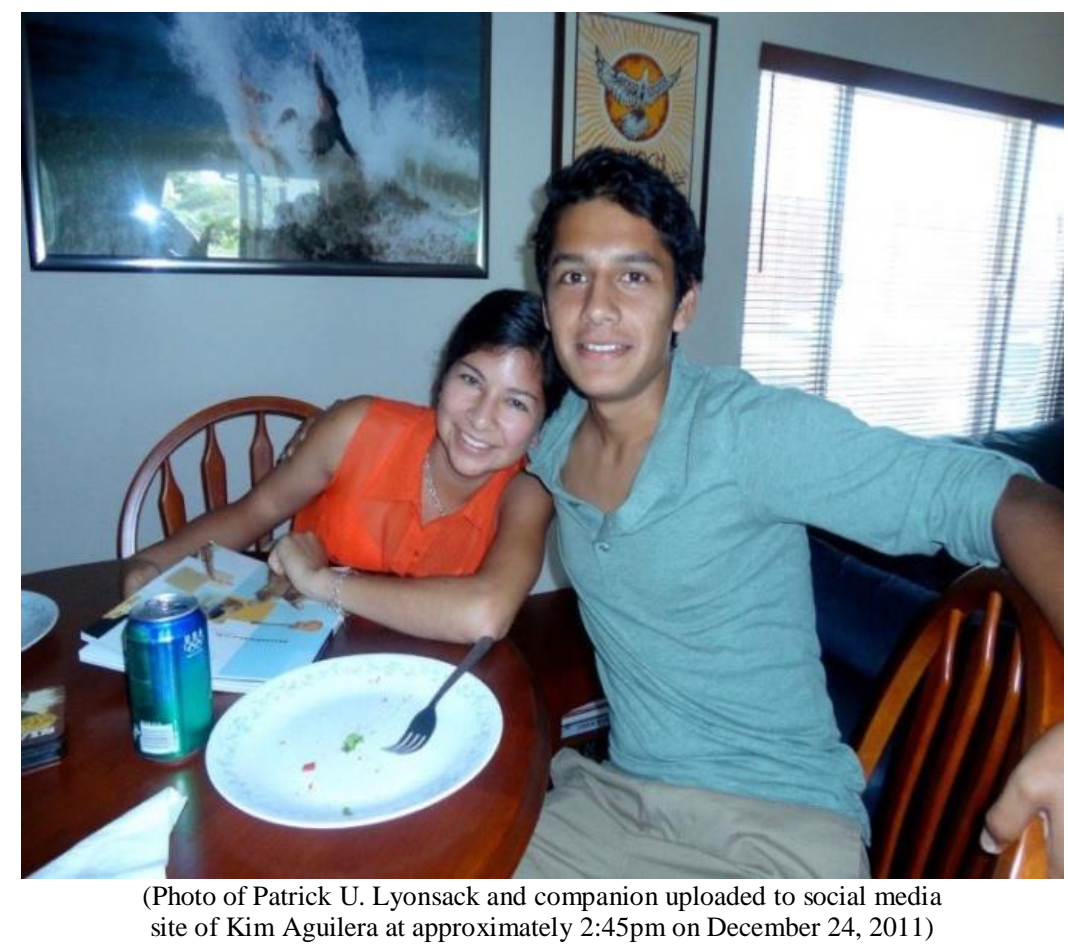

At 7:30am on Monday, December 26, Mr. Lyonsack drove directly to parking lot $F$ of the E.Z. Pickens Conglomerate, S.A. campus. He entered office building F via the east doors and remained there until 5:10pm. He left the campus at 5:10pm via his 2010 Chevrolet Camaro and traveled directly to 154 El Matador Drive, entered the home at his own will, and remained there until 7:40am the following morning, Tuesday, December 27. At that time, Mr. Lyonsack left the residence and drive directly to parking lot F of the E.Z. Pickens Conglomerate, S.A. campus. He entered office building F via the east doors and remained there until 5:05pm. 
At 5:05pm on Tuesday, December 27, Mr. Lyonsack left parking lot F of the E.Z. Pickens Conglomerate, S.A. campus and drove directly to his residence located at 456 Conquer Avenue. The 2011 Cadillac Escalade was parked in the driveway upon Mr. Lyonsack's arrival. He entered the residence and remained there until 7:30am the following morning.

On Wednesday, December 28, Mr. Lyonsack left 456 Conquer Avenue at 7:30am and drove directly to parking lot F of the E.Z. Pickens Conglomerate, S.A. campus. At the time of his departure, the 2011 Cadillac Escalade was still parked in the driveway of his residence. He remained at the campus until 5:10 pm that day at which time he departed the campus and drove directly to 456 Conquer Drive at which time my surveillance ended. I noted that the 2011 Cadillac Escalade was still parked in the driveway and had not appeared to have moved since my prior surveillance earlier that morning.

I believe this completes my report to you at this time. If you have any further questions concerning this matter, please feel free to contact me.

Sincerely,

Thomas T. Hall

Thomas T. Hall, PI

Principal, Mexico Investigations 
Exhibit 15: Patrick U. Lyonsack Employment Application

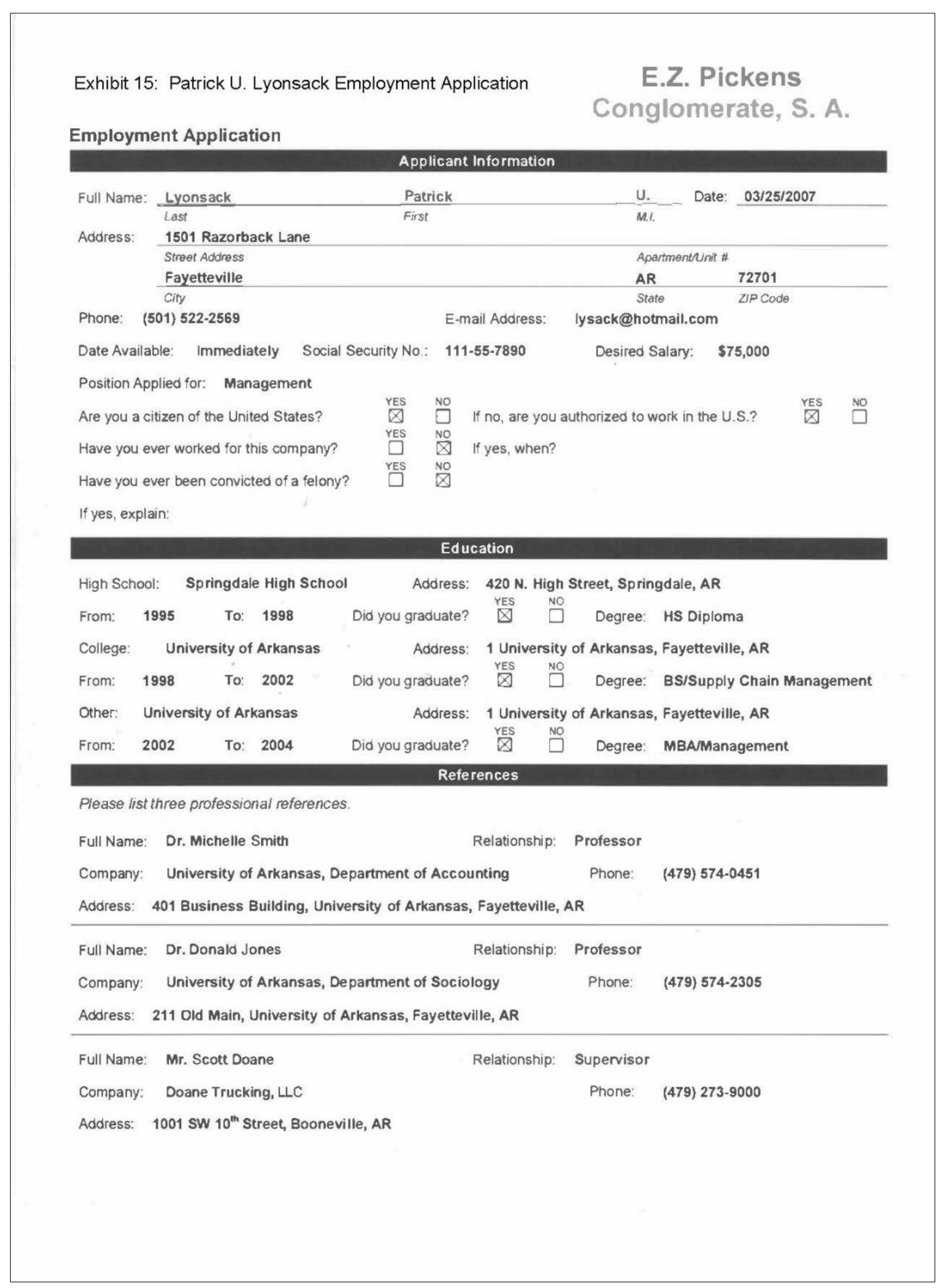


Exhibit 15: Patrick U. Lyonsack Employment Application (continued)

Exhibit 15: Patrick U. Lyonsack Employment Application

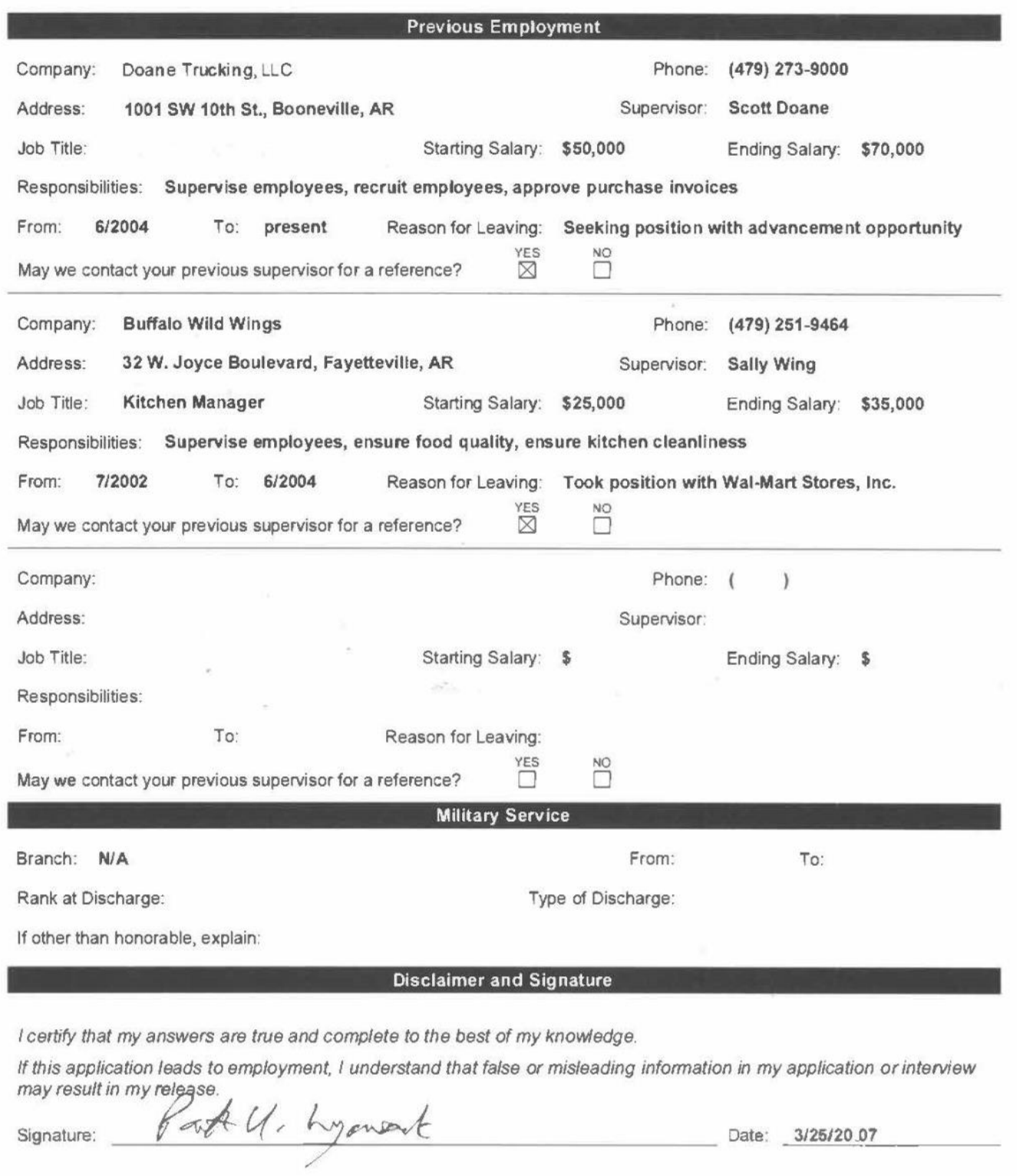


NOTES 